\title{
JACOB COME LATELY? HOSEA 12 AND THE PROBLEM OF DATING THE PATRIARCHS OF ANCIENT ISRAEL ${ }^{1}$
}

\author{
CJS Lombaard \\ Christian Spirituality \\ University of South Africa
}

\begin{abstract}
The contents of the Pentateuchal narratives on the patriarchs are given an interesting rendition in Hosea 12, a passage that seems simply to accept that its intended audience would recognise, in a sophisticated way, the allusions made to episodes from particularly the Jacob history. This passage has been widely accepted as the first extra-Pentateuchal reference to the patriarchs, with the dating accorded it usually more or less that of the time of the prophet Hosea, mid $8^{\text {th }}$ century BCE. However, based on analysis of the contents of Hosea 12, it has recently been proposed that this chapter should be dated later, which would render the Isaac references in Amos 7 the oldest extra-Pentateuchal reference to the patriarchs, dated to between 722 and 586 BCE. If the evidence holds out, this will mean that the Pentateuchal texts on the patriarchs as well as the figures they refer to (irrespective for the purposes of this article whether these figures were actual historical personages or mythical icons) are much later than they are presented as in the texts of the Pentateuch or accepted by scholarship generally.
\end{abstract}

Key Words: Hosea 12; Patriarch's History; Patriarch's Texts; Textual Dating; ExtraPentateuchal References to Patriarchs

\begin{abstract}
And Yet...
All the signs were there. Yet somehow it never really happened - at least to the extent that would be expected. Everything that would be needed to include references to the patriarchs outside the Torah but in the $\mathrm{TeNaCH}$ within the modern debate on how the Pentateuch had come into being, was in place: apart from the usual exegetical requirements (each with their own promises and limitations) of access to the texts, the language, history and archaeology, there were the particularly pertinent tools of critical philosophy of history and critical hermeneutics. Earlier indications were there (Von Bolen 1835 - cf. Ska 2011). Yet, somehow, when the 'problem of the Pentateuch', the history of its developing composition, was considered, the extra-Pentateuchal references to Abraham, Isaac and Jacob seldom played a significant role (e.g. Wahl 1997). It could be that these scant and scattered references (cf. Lombaard 2009 for an overview) were simply regarded as immaterial to the 'problem of the Pentateuch'. However, perhaps it is precisely these references to the patriarchs that occur outside the Pentateuch, most prominently in the Prophets, which could hold a key to a deeper, historically more faithful understanding of these important figures in
\end{abstract}

This article was first presented as a paper at the Sixteenth World Congress of Jewish Studies, Jerusalem, July 28-August 1, 2013. 
the religion of ancient Israel as reflected in the $\mathrm{TeNaCH}$.

In this article, the text that has traditionally been considered as containing the oldest extra-Pentateuchal reference to the patriarchs of Israel, Hosea 12, is taken into consideration. First, the text and a translation are given, after which the patriarchal references in this Hosea chapter are considered. The issue of dating the prophet, the text and the references are reviewed. This leads to considering the possibility of using the extraPentateuchal texts on the patriarchs, such as Hosea 12, as primary reference points in considering these dating options. This could namely lead to a revisioning of the time and place of the patriarchs, which if corroborated, could lead to a reconsideration of the history of ancient Israel as it relates to these primary figures.

This all is done with an acute awareness of the hypothetical nature of the analysis provided here. The intention is not in the first instance to upset received wisdom; however, if a new angle provides different possibilities of insight, closer approximation of the time and place of the patriarchs and the texts that refer to them become possible. Once the triangular relationship between 'historical' figures, the texts that portray them, and the society in which this depiction is effected is better understood, a richer depiction of the faith of ancient Israel becomes possible.

Text and Intertext: Hosea 12

\begin{tabular}{|c|c|}
\hline Hosea 12, NJPS translation & Hosea 12, BHS text \\
\hline $\begin{array}{l}{ }^{1} \text { Ephraim surrounds Me with deceit, } \\
\text { The House of Israel with guile. } \\
\text { (But Judah stands firm with God } \\
\text { And is faithful to the Holy One.) } \\
{ }^{2} \text { Ephraim tends the wind } \\
\text { And pursues the gale; } \\
\text { He is forever adding } \\
\text { Illusion to calamity } \\
\text { Now they make a covenant with Assyria, } \\
\text { Now oil is carried to Egypt. } \\
{ }^{3} \text { The Lord once indicted Judah, } \\
\text { And punished Jacob for his conduct, } \\
\text { Requited him for his deeds. } \\
{ }^{4} \text { In the womb he tried to supplant his brother; } \\
\text { Grown to manhood, he strove with a divine being, } \\
{ }^{5} \text { He strove with an angel and prevailed- } \\
\text { The other had to weep and implore him. } \\
\text { At Bethel [Jacob] would meet him, } \\
\text { There to commune with him. } \\
{ }^{6} \text { Yet the Lord, the God of Hosts, } \\
\text { Must be invoked as 'Lord.' } \\
{ }^{7} \text { You must return to your God! } \\
\text { Practice goodness and justice, } \\
\text { And constantly trust in your God. } \\
{ }^{8} \text { A trader who uses false balances, } \\
\text { Who loves to overreach, }\end{array}$ & 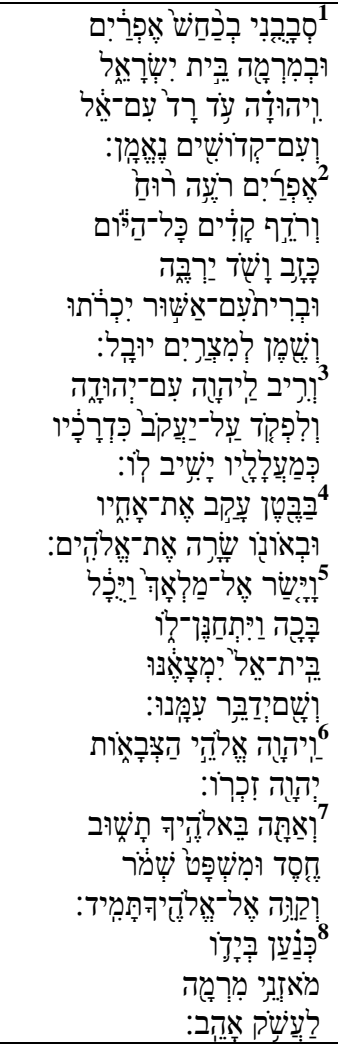 \\
\hline
\end{tabular}




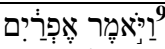

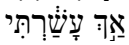

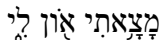

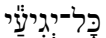

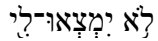

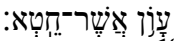

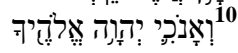

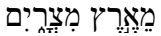

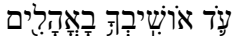

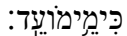

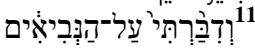

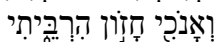

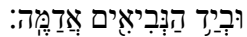

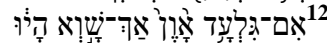

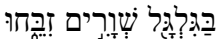

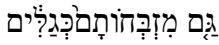

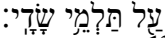

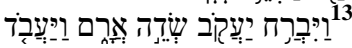

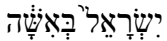

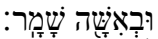

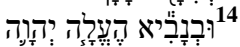

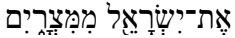

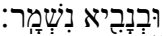

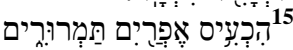

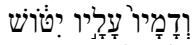

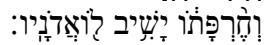

And requited him for his mockery.

As with the other extra-Pentateuchal references to the patriarchs - Isaac in Amos 7 (Lombaard 2005:152-159), Abraham in Isaiah 29:22, and the mention of all three in Psalm 105 (cf. Lombaard 2011a:139-151, Kreuzer 1989:238) - there are such strong themes in the texts surrounding the patriarchal references that these brief indications seem to disappear by comparison of importance in the interpretation of the texts. In Hosea, the themes are indeed powerful: holy instruction for the prophet to marry a prostitute; use of this relationship as a metaphor for the relationship of ancient Israel with the Divine; and then a recurring breaking of trust, namely both in the marital relationship of Hosea and in the faith relationship of Israel. The interplay between the pronouncement of judgement and the announcement of grace (historically ascribable to different editorial layers; narratologically ascribable to a tension spiral in the plot) heightens the dramatic qualities of the book of Hosea, as death and life become oscillating alternatives (cf. Levin 2006:226-236). This plays out in a broader structure for the book, which may be summarised as follows (adapted from e.g. Boshoff 2000:487; Zenger 1995:472-475; Vosloo 1992:244-252; Breytenbach 1987:738-739):

- Hosea 1-3: Israel's dalliances;

- Hosea 4-11: Divinity and youth lost;

- Hosea 12-14: The present in the light of the past.

It is, as is clear from this overall structure, within the last section of the Hosea text that 
chapter 12 is found, which itself may be structured synchronically as consisting of six parts:

1. Verses 1-3: Charge against Ephraim/Israel/Jacob, and against Judah;

2. Verses 4-5: Reference to the birth of Jacob and Esau (cf. Genesis 25:26), and to his Jabbok/Pniel struggle and his Bethel dream (cf. Genesis 32:24-32 \& 28:11-22);

3. Verses 6-12: Different issues combined (e.g. reference and allusion to the exodus);

4. Verse 13: Jacob flees and works in order to receive a wife;

5. Verse 14: Further reference to the exodus and a prophet;

6. Verse 15: A summary and a judgement.

A highly involved text diachronical with multiple references (cf. e.g. Blum 2009:291-321; Neef 1987:13-49; Diedrich 1977), the attention paid to the patriarchs in Hosea 12 may be divided into two groups: those that form part of the indictment against Ephraim/Israel/Jacob, and those that constitute a reference to the life history of Jacob as we know it from Genesis 25-35. Both these are important, though, for the topic of this article. However, two related matters draw attention too: the two references to Judah in verses 1 and 3 , and the references to prophets in verses 11 and 14 .

The references to Judah seem strongly out of place in the work of a northern prophet, and can best be ascribed to stemming from an attempt to link the name Judah to that of Jacob (cf. alternatives indicated in e.g. Yee 1987:298). The northern Hosea tradition can thus be seen here to be received within southern circles, where the apostasies of Ephraim/Israel are said to apply to Judah too, namely in a later, somewhat parallel situation to the usually assumed northern situation. The northern Hosea prophecy thus gains by means of the Judah references continued legitimacy in the south - an interpretation which would fit socio-historically either after the 722 BCE fall of Samaria to Assur (cf. recently Park 2012:98-106), as northern traditions were now preserved in the south only, or after the 587 BCE fall of Jerusalem to Babylon (cf. Young 2004:21-38). However, the attempt in these two verses, 1 and 3, to create an almost synonymous sense between the names of, on the one hand, Ephraim/Israel/Jacob and on the other hand, Judah, bespeak a situation of a merging social identity, in which the three northern names and the southern name of Judah are now all intended to refer to the same group. This attempt at identity association from a southern perspective is something which is best reflected by early post-exilic social dynamics, namely that of the confluence of diverse identities. If this likelihood holds, then the Judah reference here in Hosea 12 is certainly late; after 538 BCE, the return from the Babylonian exile.

The mention of prophets in particularly verse 14 is interesting as far as dating is concerned. Whereas the second mention is most probably an allusion to Hosea, the first allusion is clearly to the Moses figure (as is almost universally accepted by scholars). The reference to Moses as a prophet is dependent on that same description in Deuteronomy 34:10 and Deuteronomy 18:18, both of which descriptions stem from the intricate, refined debate between prophets and priests on the most significant mode of divine revelation within Israel's history: through prophecy or by means of law (cf. Otto 2006:249-250; Groenewald 2012:1-7). This kind of argument characterised post-exilic Israel, in which occurred a natural jostling for power between the different social groupings and streams, all with competing claims of legitimacy, each intended to bolster the respective discrete social positionings. Here too, as with the Judah references indicated in the paragraph above, a post-exilic dynamic can therefore be seen in the Hosea 12 text.

Is this the case with the Jacob references too? 
The episodes from Genesis 25-35 alluded to by the mention of Jacob in Hosea 12 are fairly easy to identity, as has been done in the scholarly literature (cf. e.g. Neef 1987:45-46, Breytenbach 1992:646-647, apart from the commentaries). This includes 13 (this list is from De Pury 2006:59-61, adapted by Römer 2011 and abbreviated by Bos 2013:161, with the last unbulleted line below added by him, here all slightly adapted), no, 14 such allusions:

1. twins' birth;

2. etymology of 'Jacob';

3. pushing aside of Esau;

4. struggle with the divine being;

5. etymology of 'Israel';

6. 'victory' for Jacob;

7. Bethel theophany;

8. promise: safe return under divine protection;

9. acquisition of wealth;

10. the Gilead stones;

11. Jacob flees to Aram;

12. Jacob's tenure for Leah;

13. Jacob's tenure for Rachel;

14. Hosea 12:5b as allusion to Genesis 33:4.

Clearly, the Hosea 12 text assumes among its intended readership a high level of familiarity with the Jacob material we know from the Torah, because the allusions are not explained in any detail, but are mentioned simply in passing. A kind of shorthand reference style is assumed to be enough for the intended Hosea 12 audience to recognise the episodes from Jacob's life referred to here, and from that, the implications for them.

When, before, note was taken of this level of sophistication, it was often as a passing comment. The greater surprise at this kind of refined reference, though rarely noted, has been reserved for the unexpected phenomenon that it takes such a long time for reference to the patriarchs to occur outside the Torah. How could it be that such an important part of ancient Israel's faith history is not made mention of for so long, outside the Torah?

This evaluation by scholars was made in the context of the traditional critical dating accorded the respective literatures; that means, with the Pentateuchal texts springing from the $10^{\text {th }}$ and $9^{\text {th }}$ century BCE and the Hosea text coming from the mid to late $8^{\text {th }}$ century $\mathrm{BCE}$. Given this traditional critical time frame, that leaves as the real surprise the century to two of total silence on the patriarchs of Israel outside the Genesis texts (Von Bolen 1835 cf. Ska 2011, noted above; cf. Lombaard 2013).

On further reflection, though, perhaps such an assessment would be unfair: in which literature from the Hebrew Bible would such reference namely have occurred? Apart from possibly the wisdom literature, a genre of literature not really suited to historical referentiality (cf. however the Hellenistic book Wisdom of Solomon 10:10-12, which alludes to Jacob-Witte 2009:323-346), not much literature had come into existence outside the Torah that could incorporate such references. This concern holds true, though, only within the traditional critical time frames accorded the Torah and the Hosea texts.

However, much has changed in recent decades on the traditional critical dating of the 
Pentateuchal sources (cf. the brief summary in de Pury 2006:54), and in recent years on the dating of Hosea 12 (Lombaard 2013, drawing on e.g. Römer 2011). Of the former, it has now been concluded to a substantial consensus that not much happened on the book of Deuteronomy, for instance, prior to the time of King Josiah (mid $7^{\text {th }}$ century), with the 'discovery' of sections of what we now know as Deuteronomy 12-26 in the temple, as indicated in 2 Kings 22-24 (cf. Otto 2007:19-28, going back to De Wette 1805). Although wisdom, legal and poetic material had existed before that time, the beginning of the grand writing project of Israel's past - and always by direct implication, the present, at the time of writing - may be partially pinpointed to this 'discovery'. This much is known well enough among Bible scholars now.

On Hosea 12, the cases for a later dating have been made much more recently. Going against received opinion (e.g. Blum 2009:291-321, Boshoff 2000:487, Breytenbach 1987:739), arguments for a post-exilic dating of specifically Hosea 12 have been put forward (Römer 2011, drawing on Nissinen 1991 and others; cf. Lombaard 2013). These arguments have included that at the very least a deuteronomistically oriented redaction of the Hosea 12 text seems theologically evident; that the link between the Jacob traditions and those of Abraham and Isaac seems more likely post 722 and post 587; ditto, the link, as opposition, with the Moses figure; and also the maturity of the references to the patriarchal narratives. However, Bos (2013:165-170) has very recently put forward forceful arguments for why the whole of the Hosea book, thus including chapter 12, ought to be dated late in the $6^{\text {th }}$ or early in the $5^{\text {th }}$ century BCE: the sociological placement of anti-monarchical pronouncements and the historical aptness of e.g. place names are just so much stronger during that time than during any other.

This growing sense on understanding the text of Hosea 12 in a less convoluted manner makes for an ever more likely acceptance of a post-exilic, early Second Temple period origin for this chapter.

However, does this origin refer to the text or to its contents?

\section{Patriarchal History and Hosea 12}

Despite the refined, sophisticated Jacob references that we find in Hosea 12, this text tells us nothing about how far these traditions go back in their historical trajectories (Kreuzer 1989:225-227). The 'Geschichtsrückblicke' (Vielhauer 2007:178) offered by Hosea 12 on Jacob has been accepted in all but very few publications as going back far - half a millennium, often, and at times double that, between narrated event and time of narration.

Always then, though, the Hosea 12 text had been dated to the $8^{\text {th }}$ century and the relevant Pentateuch texts to a century and two earlier. The oral traditions said to carry these accounts through the mists of time until they came into writing, were therefore said to be kept alive for multiple centuries.

However, based on the references in Hosea 12 to Judah, to the prophets and to Jacob, it is now possible to move our understanding of the origination of this text to the other side of the exile, namely to our side, so that it is now younger than 538 BCE. Though initially unsettling, with Abraham already accepted by scholars as a primarily exilic/post-exilic figure, coming to the fore for the first time outside the Pentateuch within the Deutero-Isaiah texts, a similar understanding of Jacob is not as radical as might at first be assumed.

Still, would this change matters?

Namely, with a younger Hosea 12 text: 
- would an even longer historical trajectory for the patriarchal narratives have to be postulated, until they find firmer ground in the text of Hosea 12?;

- and, would the historical veracity of the patriarchal figures be questioned even more fiercely now by those so inclined?;

- or, would a recently proposed understanding of the patriarchal figures as themselves much younger than had traditionally been assumed (Lombaard 2013, Lombaard 2011b:470-486) now become more viable? Or perhaps it would be wrought with even more difficulties...

All these possibilities, and more, exist.

Only when the interaction between the patriarchal figures, the Pentateuchal and extraPentateuchal texts that portray them, and the society in which these re/presentations came into being, are comprehended more fully, will a richer description of the history and the religion of ancient Israel in the different phases of its existence be viable.

All the signs are here that we should think anew.

\section{BIBLIOGRAPHY}

Bos, JM 2013. Reconsidering the date and provenance of the book of Hosea: The case for Persian-period Yehud. London: Bloomsbury T\&T Clark.

Boshoff, WS 2000. Ou Testamentiese literatuur uit die Noordryk (Israel) - die neerslag van noordelike tradisies in die Ou Testament. Skrif en Kerk 21/3:473-494.

Blum, E 2009. Hosea 12 und die Pentateuchüberlieferungen, in Hagedorn, AC \& Pfeiffer, H (Hrsg.) Die Erzväter in der biblischen Tradition. Festschrift für Matthias Köckert (BZAW 400). Berlin: de Gruyter, 291-321.

Breytenbach, APB 1992. Pentateugtradisies in die boek Hosea. Hervormde Teologiese Studies 48:645-662.

Breytenbach, APB 1987. Die redaksionele geskiedenis van die boek Hosea. Hervormde Teologiese Studies 43:732-740.

De Pury, A 2006. The Jacob story and the beginning of the formation of the Pentateuch, in Dozeman, TB \& Schmid, K (eds.) A farewell to the Yahwist? The composition of the Pentateuch in recent European interpretation. Leiden: Brill, 51-72.

De Wette, WML 1805. Dissertatio critico-exegetica qua Deuteronomium a prioribus libris diversum, alius cujusdam recentioris auctoris opus esse monstratu. Jena: s.n.

Diedrich, F 1977. Die Anspielungen auf die Jakob-Tradition in Hosea 12,1-13,3.

Ein literaturwissenschaftlicher Beitrag zur Exegese früher Prophetentexte. Würzburg: Echter Verlag.

Groenewald, A 2001. Isaiah 1:2-3 and Isaiah 6: Isaiah 'a prophet like Moses' (Dt 18:18). HTS Teologiese Studie s /Theological Studies 68/1, Art. \#1311, 7 pages. http://dx.doi.org/10.4102/ hts.v68i1.1311.

Kreuzer, S 1989. Die Frühgeschichte Israels in Bekenntnis und Verkündigung des Alten Testaments (BZAW 178). Berlin: de Gruyter.

Lee, DS 1990. Studies in the text and structure of Hosea 12-14 (PhD dissertation). Edinburgh: University of Edinburgh. 
Levin, A 2006. A new context for Jacob in Genesis and Hosea 12, in Wood, JR, Harvey, JE \& Leuchter, M (eds.) From Babel to Babylon. Essays on Biblical History and Literature in honour of Brian Peckham. New York: T\&T Clark, 226-236.

Lombaard, C 2013. Three old men? The patriarchs in the Prophets (Or: what do patriarchs look like, and where do we find them?). Paper read at the Old Testament Society of South Africa annual congress, 7-9 September 2011, University of the Western Cape, Cape Town, South Africa; further developed for the Research Day of the Unit for Old Testament and Ancient Near Eastern Studies, Department of Biblical and Ancient Studies, University of South Africa, Pretoria, South Africa, 25 April 2013. Publication forthcoming: Tydskrif vir Semitistiek/Journal for Semitics 2013.

Lombaard, C 2011a. Argumentum ex (fere) silentio. Reconsidering the (almost) silence on the patriarchs in the Psalter. Tydskrif vir Semitistiek/Journal for Semitics 20/1:139-151.

Lombaard, C 2011b. The Patriarchs and their Pentateuchal references: outlines of a new understanding. Tydskrif vir Semitistiek/Journal for Semitics 20/2:470-486

Lombaard, C 2009. Isaac in the Old Testament. A new interpretation from Genesis 22, based on hermeneutical-methodological and exegetical investigations (DD dissertation). Pretoria: University of Pretoria.

Lombaard, C 2005. What is Isaac doing in Amos 7?, in Otto, E \& Le Roux, J (eds.) A critical study of the Pentateuch. An encounter between Europe and Africa (Altes Testament und Moderne 20). Munich: LIT Verlag, 152-159.

Nissinen, M 1991. Prophetie, Redaktion und Fortschreibung im Hoseabuch. Studien zum Werdegang eines Prophetenbuches im Lichte von Hos 4 und 11. Kevelaer: Butzon \& Bercker.

Otto, E 2007. A hidden truth behind the text or the truth of the text: at a turning point of biblical scholarship two hundred years after De Wette's Dissertatio CriticoExegetica, in le Roux, J \& Otto, E (eds.) South African perspectives on the Pentateuch between synchrony and diachrony. New York: T\&T Clark International, 19-28.

Otto, E 2006. Der Pentateuch im Jeremiabuch. Überlegungen zur Pentateuchrezeption im Jeremiabuch anhand neuerer Jeremia-Literatur. Zeitschrift für altorientalische und biblische Rechtsgeschichte 12, 245-306.

Park, SJ 2012. A new historical reconstruction of the fall of Samaria. Biblica 93, 98-106.

Römer, T 2011. Older (pre-exilic) traditions in the Torah - the case of the patriarchal and the Moses traditions. Tel Aviv: The Ancient Israel Studies Program, Department of Archaeology and Ancient Near Eastern Cultures, Tel Aviv University, Scholarly Seminar Series.

Ska, J-L 2011. Anything new under the sun of Genesis? Paper read at the Society of Biblical Literature's annual international conference, 3-7 July 2011, King's College London.

Von Bohlen, P 1835. Die Genesis historisch-kritisch erläutert. Königsberg: Verlag der Gebrüder Borntrüger.

Vielhauer, R 2007. Das werden des Buches Hosea. Eine redaktionsgeschichtliche Untersuchung. Berlin: Walter de Gruyter.

Vosloo, W 1992. Die samestelling en struktuur van die boek Hosea. Skrif en Kerk 13/2:244-252. 
http://scriptura.journals.ac.za

Jacob come lately? Hosea 12 and the Problem of Dating the Patriarchs of Ancient Israel 9

Wahl, HM 1997. Die Jakobserzählungen. Studien zu ihrer mündlichen Überlieferung, Verschriftung und Historizität. Berlin: Walter de Gruyter.

Witte, M 2009. Jakob der Gerechte - Beobachtungen zum Jakobsbild der Sapientia Salomonis (Sap 10,10-12), in Hagedorn, AC \& Pfeiffer, H (Hrsg.) Die Erzväter in der biblischen Tradition. Festschrift für Matthias Köckert (BZAW 400). Berlin: De Gruyter, 323-346.

Yee, GA 1987. Composition and tradition in the book of Hosea. A redaction critical investigation. Atlanta: Scholars Press.

Young, RC 2004. When did Jerusalem fall? Journal of the Evangelical Theological Society 47/1: 21-38.

Zenger, E 1998. Das Buch Hosea, in Zenger, E (Hrsg.). Einleitung in das Alte Testament (3. Auflage). Stuttgart: Kohlhammer Verlag, 472-478. 